\title{
RESERVATIONS AS UNILATERAL ACTS? EXAMINING THE INTERNATIONAL LAW COMMISSION'S APPROACH TO RESERVATIONS
}

\author{
Рок Yin S. CHоw*
}

\begin{abstract}
The law of unilateral acts and the law of treaties are generally considered to be two distinct areas of international law. While the former governs the effect of unilateral undertakings by States, the latter governs, inter alia, the formation, interpretation, termination, and suspension of treaties. In 2011, the International Law Commission (ILC) concluded a two-decade study on reservations. One of its most remarkable insights is the argument that reservations ought to be considered 'unilateral acts'. Thus, certain rules pertaining the law of unilateral acts ought to apply to reservations. This article critically examines the ILC's novel proposal as well as its attempt to provide answers to contemporary questions on reservations through conceptualizing reservations as unilateral acts.
\end{abstract}

Keywords: ILC Guide to Practice on Reservations to Treaties, multilateral treaties, reservations, unilateral acts, Vienna Convention on the Law of Treaties.

\section{INTRODUCTION}

States that wish to become parties to a multilateral treaty, but are reluctant to be bound by the treaty in full, invariably resort to reservations. Reservations serve to modify or exclude the legal effects of treaty provisions. They are often deployed to either limit the obligations undertaken by the reserving State or to enable the discharge of treaty obligations by equivalent means. ${ }^{1}$

Contemporary international law governing reservations developed from the International Court of Justice's (ICJ) 1951 Reservations to the Genocide Convention Advisory Opinion (Genocide Convention Advisory

* Visiting Research Fellow, City University of Hong Kong, stephensonchow@gmail.com. The author is indebted to Dr Phil CW Chan, Dr Eric C Ip, Dr Eva Kassotti, Dr Adamantia Rachovitsa and Dr Pei-lun Tsai for their insightful comments on a previous draft and also to the anonymous reviewers for their thoughtful suggestions. The author would like to thank Laura Graham and Dr Ying Khai Liew for their comments on language. Any errors or omissions remain my own.

1 See JK Gamble Jr, 'Reservations to Multilateral Treaties: A Macroscopic View of State Practice', (1980) 74 AJIL 372, 383-91; see also RW Edwards, 'Reservations to Treaties' (1989) 10 MichJInt'IL 362; D Shelton, 'State Practice on Reservations to Human Rights Treaties' (1983) CanHumRtsYB 205; J Galbraith, 'Treaty Options: Towards a Behavioral Understanding of Treaty Design' (2013) 3(2) VaJInt'lL. 309. 
Opinion). ${ }^{2}$ The Genocide Convention Advisory Opinion laid down important principles for the operation of reservations including, inter alia, that unanimous acceptance of reservations is not required unless expressly stipulated, and that reservations are illegal if they contravene the object and purpose of a treaty. ${ }^{3}$ These elements were subsequently incorporated into the Vienna Convention on the Law of Treaties (Vienna Conventions), ${ }^{4}$ the single most important instrument on the law of treaties, forming the bedrock of international treaty law today. The introduction of these concepts, however, also gave rise to some of the most complex questions in international law. ${ }^{5}$ Among the deeply perplexing questions are: whether the object and purpose test is an objective or subjective test $;{ }^{6}$ whether dispute settlement mechanisms have the competence to assess reservations; ${ }^{7}$ whether an acceptance may save a reservation that is otherwise incompatible with the object and purposes of a treaty $;^{8}$ and whether impermissible reservations are severable. ${ }^{9}$ These questions arose as a result of a paradigm shift away from a contractual model of treaty relations, under which the decision whether a reservation could have any legal significance at all depended solely on the reactions of its addressees.

In 1993, the International Law Commission (ILC) committed itself to the monumental task of clarifying some of the aforementioned uncertainties. ${ }^{10}$ Through 18 years of extensive research and deliberations, in 2011, the ILC produced the Guide to Practice on Reservations to Treaties and its Commentary (Guide to Practice and Commentary). ${ }^{11}$ Among the notable suggestions proposed, one remarkable view concerned how the ILC chose to conceptualize reservations as 'unilateral acts'. ${ }^{12}$ At first sight, this may seem

2 Advisory Opinion Concerning Reservations to the Convention on the Prevention and Punishment of the Crime of Genocide, Advisory Opinion of 28 May 1951, 1951 ICJ Rep 15.

3 ibid 18.

4 (adopted 23 May 1969, entered into force 27 January 1980) 1155 UNTS 331 (Vienna Convention).

5 DR Anderson, 'Reservations to Multilateral Conventions: A Re-examination' (1964) 13 ICLQ 450.

6 See eg A Pellet, 'Article 19' in O Corten and P Klein (eds), The Vienna Conventions on the Law of Treaties: A Commentary vol 1 (Oxford University Press 2011) 405, 425.

7 See eg R Baratta, 'Should Invalid Reservations to Human Rights Treaties be Disregarded?' (2000) 11(2) EJIL 413, 415-16.

8 DW Bowett, 'Reservations to Non-Restricted Multilateral Treaties' (1976-77) 48 BYBIL 67; JK Koh, 'Reservations to Multilateral Treaties: How International Legal Doctrine Reflects World Vision' (1982) 23 HarvInt'lLJ 71.

9 KL McCall-Smith, 'Severing Reservations' (2014) 63(3) ICLQ 599.

10 For an account of the background to the Guide to Practice, see A Pellet, 'The ILC Guide to Practice on Reservations to Treaties: A General Presentation by the Special Rapporteur' (2013) 24(4) EJIL1061.

11 ILC 'Guide to Practice on Reservations to Treaties' (2011) UN Doc A/66/10, para 75 (Guide to Practice and Commentary).

12 The Commentary to the Guide to Practice makes multiple references to reservations as unilateral acts. For example the Commentary to the Guide to Practice notes that: "[s]ince reservations are unilateral acts, the Commission based itself on the guidelines for interpreting such acts contained in the Guiding Principles applicable to unilateral declarations of States 
redundant - after all, reservations are widely accepted as 'unilateral statements' as defined in the Vienna Convention. ${ }^{13}$ On second thoughts, however, this conceptualization might be problematic. If a reservation is a unilateral act, which body of rules - the law of unilateral acts or the law of treaties - should govern the use and effect of reservations? Given that the law on unilateral acts and the law of treaties are widely considered distinct areas of international law, in that they address very different contexts and concerns, characterizing reservations as unilateral acts appears inappropriate.

Surprisingly, the ILC's answer to the above question is that the law of unilateral acts should indeed govern certain aspects of reservations. ${ }^{14}$ This is a conclusion that is seemingly inconsistent with the approach taken in the ILC's 2006 Guiding Principles Applicable to Unilateral Declarations of States Capable of Creating Legal Obligations (2006 Guiding Principles on Unilateral Declarations), which categorically excluded reservations from its ambit of study. ${ }^{15}$ One rationale is that a reservation does not only attach to an international agreement but also attaches to the manifestation of consent to be bound by the international agreement, the latter of which comes very close to a 'unilateral act' in international law. ${ }^{16}$ Nevertheless, the ILC argued that when applying the laws of unilateral acts on reservations, rules and principles must be interpreted in the light of the specific circumstances of reservations, ie that reservations necessarily arise in the context of an existing international agreement. ${ }^{17}$ This implies that, while rules governing the above aspects of reservations may derive from principles applicable to unilateral acts, such

capable of creating legal obligations, which it adopted in 2006'. See Guide to Practice and Commentary (n 11) 374, 467-468.

${ }^{13}$ Art 1(d), Vienna Convention. The definition of a reservation under art 1(d) of the Vienna Convention has arguably attained the status of customary international law; see English Channel Arbitration (1979) 18 ILM 397; Temeltasch v Switzerland (1982) DR 31; Belilos v Switzerland ECtHR Ser A (1988) vol 132, para 46.

14 cf I Brownlie, Principles of International Law (7th edn, Oxford University Press 2008) 61213 , the validity of a reservation 'is determined on a contractual and not a unilateral basis'.

${ }_{15}$ The Yearbook of the International Law Commission 1997, Vol II, Pt Two, UN Doc A/CN/ Ser.A/1997/Add.1 (Part 2), 65, paras 203-204. The ILC Working Group on the Unilateral Acts of States remarked that: 'The Working Group bore in mind that, in the process of treaty formation, amendment, execution, termination, etc., States carry out acts which, prima facie, are unilateral in character when viewed in isolation (for example, accession, denunciation, reservation, withdrawal). The Group nonetheless considered that the characteristics and effects of such acts are governed by the law of treaties and do not need to be dealt with further in the context of the new study proposed.' In other words, from the point of view of the Working Group, reservations, being a specific type of unilateral act, should be governed by the law of treaties lex specialis.

${ }_{16}$ Guide to Practice and Commentary (n 11) 91; L Lijnzaad, Reservations to the UN-Human Rights Treaties: Ratify and Ruin? (Martinus Nijhoff Publishers 1995) 38, 'Whereas the drafting of treaties tends to be an increasingly multilateral process; the expression of consent to be bound remains a unilateral act'; K Zemanek, 'Unilateral Legal Acts Revisited' in K Wellens (ed), International Law, Theory and Practice: Essays in Honour of Eric Suy (Martinus Nijhoff Publishers 1998) 209, 210, '[t] he consent to be bound by a multilateral convention is expressed by a unilateral act, such as signature, ratification or accession, not by concurring wills'.

17 In the words of the ILC, although reservations are unilateral acts, they are 'non-autonomous' and do not generate exogenous effect. See Guide to Practice and Commentary (n 11) 470. 
rules should also be interpreted in the context of treaties. ${ }^{18}$ As shall be demonstrated in this article, the result is an innovative 'hybrid' approach where the law of unilateral acts and the law of treaties overlap in the context of reservations. The former is applicable when consent is at issue (eg when determining the scope of a reservation and the consequences of its invalidity), while the latter continues to govern, inter alia, formal procedures, including the termination, withdrawal, and suspension of reservations.

This article examines the ILC's arguments and explains in detail how the ILC attempted to resolve contemporary questions on reservations by conceptualizing them as unilateral acts. After highlighting the significance of the approach taken by the ILC to existing debates, this article further attempts to predict the potential influence of this approach on future international law and practice.

Section II of the article provides an overview of the debates surrounding rules applicable to reservations, setting out the context of the present article. Section III will revisit the law of unilateral acts. It will identify features of reservations that resemble unilateral acts recognized in international law. Section IV examines how the Guide to Practice approaches reservations and analyses the consequences of viewing reservations as unilateral acts in terms of their timing of existence, justiciability, and interpretation. In particular, it explains how rules concerning reservations may be different when they are considered 'nonautonomous' unilateral acts. This section will also attempt to predict the effects of the ILC's emphasis on the unilaterality of reservations on the future practice of reservations. It explains why the approach adopted by the Guide to Practice will render the effects of reservations more predictable. It also explains why, instead of eroding mutual consent, the stress in 'unilaterality' paradoxically better preserves the mutual consent of States in the practice of reservations.

\section{THE ORIGINS OF THE DEBATES CONCERNING APPLICABLE RULES ON RESERVATIONS}

Directly inspired from the notion of contract, customary international law prior to the League of Nations dictated that a reservation must be accepted by all parties to a treaty before the reserving State could itself become a party. This is often referred to as the principle of unanimity. ${ }^{19}$ Under this principle, whether a reservation was valid and whether it was to have any effect at all depended solely on the addressee State(s). Yet, during the period of the League of Nations, State practice concerning reservations to multilateral treaties revealed serious inconsistencies. While the League Secretariat (later the Secretary-General of the United Nations) adopted the principle of

\footnotetext{
18 ibid 467-8.

19 Genocide Convention Advisory Opinion (n 2) 24; Lijnzaad (n 16) 66; M Coccia, 'Reservations to Multilateral Treaties on Human Rights' (1985) 15 CalWInt'lLJ 1, 26-7.
} 
unanimity, the Pan-American Union (later the Organization of American States) allowed a reserving State to become a party to a multilateral treaty vis-à-vis nonobjecting States. ${ }^{20}$

In 1948, the adoption of the Convention on the Prevention and Punishment of the Crime of Genocide by the United Nations General Assembly (UNGA) prompted questions over the admissibility of reservations. ${ }^{21}$ This resulted in a request to the ICJ for an advisory opinion. With the bench divided, the majority in the Genocide Convention Advisory Opinion adopted a 'flexible approach' by allowing a reserving State to become a party to the Convention as long as the reservation is not incompatible with the object and purpose of the Convention; it is with reference to the object and purpose of the treaty that States shall furnish their objections. ${ }^{22}$ The rationale for this approach was that States should not be prevented from becoming a party to the Convention if their reservations were only marginal. ${ }^{23}$ It was thought that this would increase the participation of States in ratifying multilateral treaties - thus enhancing the process of the codification of international law through the use of treaties ${ }^{24}$-while maintaining a sufficient level of treaty integrity to enable treaties to operate effectively. ${ }^{25}$

The Genocide Convention Advisory Opinion had an enduring impact on the development of the law of treaties. Articles 19-23 of the Vienna Convention, which govern applicable rules on reservations, incorporated concepts expounded previously by the ICJ, including, most prominently, the object and purpose test. Yet, the notion also gave rise to deeply troubling questions. In particular, Article 19(c) provided that a State may not formulate a reservation if the reservation is incompatible with the object and purpose of the treaty. ${ }^{26}$ Meanwhile, Articles 20(4)(a) and 21(1)(a) respectively provided that '[a]cceptance by another contracting State of a reservation constitutes the reserving State a party to the treaty' 27 and that such an acceptance '[m]odifies for the reserving State in its relations with that other party the provisions of the treaty to which the reservation relates to the extent of the reservation'.28 Therefore, what would be the effect of the acceptance of a reservation that may reasonably be said to be incompatible with the object and purpose of the treaty? If the object and purpose test is essentially a subjective test, ie a matter wholly for the accepting State to decide, then the acceptance of a reservation pursuant to Article 20(4) suffices to render a reservation valid regardless of its prima facie incompatibility. On the other hand, if the object and purpose

${ }^{20}$ Brownlie (n 14) 612-13; The origins of the Pan-American practice could be traced to the Havana Convention of 29 February 1928. For an analysis, see Pellet (n 6) 410.

21 (adopted 9 December 1948, entered into force 12 January 1951) 78 UNTS 277.

22 Genocide Convention Advisory Opinion (n 2) para 24.

24 J O'Brien, International Law (Routledge 2001) 337.

25 Genocide Convention on Advisory Opinion (n 2) para 24; M Morris, 'Few Reservations about Reservations' (2000) 1 Chicago Journal of International Law 341, 343.

${ }^{26}$ Art 19(3), Vienna Convention. $\quad 27$ Art 20(4)(a) ibid. $\quad{ }^{28}$ Art 21(1)(a) ibid. 
test is essentially an objective test, then Article 19(3) should trump Article 20(4) - even though this would give rise to another question: which international judicial/quasi-judicial bod(ies) shall have the authority to pronounce on the invalidity of such reservations ${ }^{29}$ Moreover, since a reservation objected to by another State on grounds of incompatibility would not automatically preclude the reserving State from becoming a party to the multilateral treaty, ${ }^{30}$ what would be the legal consequence of a reservation subsequently found incompatible (assuming there is a competent third party to adjudicate on the permissibility of reservations)? These unresolved questions form a core part of the very enigma that continues to puzzle international lawyers today.

\section{CONSTRUING RESERVATIONS AS UNILATERAL ACTS}

Construing reservations as unilateral acts is an altogether different way of imagining reservations. A unilateral act in international law refers to an unequivocal expression of will formulated publicly by one State to other State(s) or international organization(s), committing to acquire certain international legal obligations. ${ }^{31}$ The very concept of a unilateral act implies that a State may, through its own will manifested publicly, undertake to abide by a course of conduct or otherwise oblige itself legally. ${ }^{32} \mathrm{~A}$ unilateral act is so described because it generates legal effects unilaterally, as opposed to international agreements and treaties where obligations are created by consensus, ie through the 'meeting of minds'. ${ }^{33}$

29 S Wei, 'Reservations to Treaties: Some Practical Issues' (1997) 7 AsianYrbkIntlL 105, 118; ET Swaine, 'Reserving' (2016) 31 YaleJIL 307, 315-16; Koh (n 8) 76.

30 An objection to a reservation will not preclude a reserving State from becoming a party to the treaty if the reservation is accepted by another State, unless the treaty specifies unanimous consent as a requirement, or where it concerns a multilateral treaty with a limited number of negotiating States in accordance with art 20(2) of the Vienna Convention. Art 20(4)(c) of the Vienna Convention provides that 'an act expressing a State's consent to be bound by the treaty and containing a reservation is effective as soon as at least one other contracting State has accepted the reservation'.

31 See VR Cedeno, Second Report on Unilateral Acts of States, UN Doc A/CN.4/500 (1999) para 38; ILC, Report of the Working Group, UN Doc A/CN.4/L.588 (1999) para 10.

32 C Eckart, Promises of States under International Law (Hart Publishing 2012) 38.

33 ibid 40; Nuclear Tests (New Zealand v France), Judgment, 1974 ICJ Rep 267 (Nuclear Tests Case); Case Concerning the Frontier Dispute (Burkina Faso v Republic of Mali), Judgment of 22 December 1986, 1986 ICJ Rep 573 (Frontier Dispute Case) at paras 43, 44; at present, there is 'no all-encompassing uniform and precise definition of unilateral acts'. One primary obstacle to defining unilateral acts is the debatable legal basis upon which unilateral acts derives its legally binding character, ie whether it derives from the voluntary nature of the act, the principle of estoppel, or the principle of good faith (upon which a certain level of trust or reliance has been placed on the act by another party). Nevertheless, it is clear that a unilateral act strictly defined in international law is one that is capable of bringing about a unilateral effect. In particular, a unilateral act concerns a unilateral undertaking to international obligations. See Zemanek (n 16) 210; A McNair, The Law of Treaties (Oxford University Press 1961) 486-7; A Weingerl, 'Definition of Unilateral Acts of States' (2004) <http://www.esil-sedi.eu/sites/default/files/Weingerl_0.PDF>; The 2006 Guiding Principles on Unilateral Declarations defines unilateral acts stricto sensu as 
The view that reservations are essentially 'unilateral' is not completely novel, although the understanding of 'unilaterality' has dramatically changed. Prior to the Vienna Convention, socialist States held the theory that a reservation would modify treaty relations regardless of the acceptance of other State parties. ${ }^{34}$ This is because the making of a reservation is an exercise of State sovereignty, which should not in any event be undermined. ${ }^{35} \mathrm{~A}$ reservation was thus considered a unilateral act in the sense that it is an act conducted unilaterally and was capable of generating legal effects - even though the emphasis was not placed on the sovereign capacity to acquire legal obligations, but rather the capacity to exclude them. This view, however, was soon marginalized because it was felt that the consent of the addressee States were not properly taken into account. The principle of unanimity was then favoured; according to this principle a reservation is often perceived as forming part of a negotiated international agreement because the consent of the existing State parties is always required. ${ }^{36}$

Nevertheless, the Vienna Convention embraces neither conception. Under the Vienna Convention, States have the right to formulate and withdraw reservations, although consent is still required for reservations to take effect. $^{37}$ Thus, the operation of reservations embodies both unilateral and bilateral elements: 'they are made unilaterally, are accepted or objected to unilaterally... [but] ultimately function in a reciprocal way'. ${ }^{38}$ Therefore, even where there are multiple stages at which 'unilaterality [would cast] its shadow', 39 reservations are generally not considered unilateral acts under international law for it is impossible to generate legal effects unilaterally.

'those taking the form of formal declarations formulated by a State with the intent to produce obligations under international law'.

${ }^{34}$ United Nations Conference on the Law of Treaties, Official Records, vol III, at 265; J Triska and R Slusser, The Theory, Law and Policy of Soviet Treaties (Stanford University Press 1962) 86.

35 Lijnzaad (n 16) 31.

36 ibid. '[t]he main difference between the socialist doctrine and the traditional doctrine concerned the appreciation of the unilateral character of reservations. Both doctrines held different views on the contractual nature of treaty law and the emphasis put on sovereignty as the sacred core of the state's international existence.'

37 Coccia (n 19) 26-8; arts 1(d) and 21 of the Vienna Convention. The definition of a reservation in the Vienna Conventions prescribes that a reservation is a statement unilaterally made. The effect of the reservation, however, depends on the addressee. In principle, a reservation is operative between the corresponding States only if expressly or tacitly accepted. cf The Effect of Reservations on the Entry Into Force of the American Convention on Human Rights (Arts. 74 and 75), Advisory Opinion OC-2/82, 24 September 1982, Inter-AmCtHR (Ser. A) No.2 (1982) paras 37-38 (Effect of Reservations on the Entry into Force of IAmCHR), where the InterAmerican Court of Human Rights concluded that owing to the unique characteristics of human rights treaties in general and the Inter-American Convention on Human Rights in particular, 'reservations compatible with the object and purpose of the Convention, do not require acceptance by the State Parties... [these reservations] enter into force... as of the moment of their deposit'.

38 Lijnzaad (n 16) 32.

39 ibid 65 . Another way of describing reservations is that reservations are only unilateral acts in form (ie they are 'unilateral statements' made from one State to another) but not in substance. 
Nonetheless, even if reservations are not considered unilateral acts in the strict sense, ${ }^{40}$ they resemble unilateral acts in two fundamental ways. Firstly, by necessary implication, unilateral acts embody the element of nonparticipation. ${ }^{41}$ The 1997 Report of the Working Group on Unilateral Act of States remarked that:

The fundamental characteristic of unilateral legal acts is, logically, their unilateral nature. They emanate from one single side (from the Latin 'latus'), in other words, from one or several subjects of international law acting 'unilaterally' and the participation of another party is not required. ${ }^{42}$

A unilateral act is a 'manifestation of the will of one or more States in individual, collective or concerted form, in which other States, and in particular the addressee State, do not participate'. ${ }^{43}$ The validity of such acts is often attributed to the capacity of States to consent unilaterally to legal undertakings without creating obligations on another. ${ }^{44}$ Similarly, reservations are unilateral in the sense that their formulations do not require the participation of the addressee. ${ }^{45}$ They assume a unilateral character in the sense that they are only 'proposals'. Writing in 1957, Fitzmaurice noted that:

In the strict sense, all reservations, even those which it has been agreed in advance may be made (where such is the case), are unilateral inasmuch as any particular reservation is only the act of, and privy to, the particular country making it, and only relates to its own obligations under the treaty ... [T] he reservation is unilateral not only in form but in substance and at that stage, is strictly only entitled by courtesy to be called a reservation, for in principle until the reservation is admitted and accepted, expressly or sub silentio, it is only a proposal and not a completed and operative reservation. ${ }^{46}$

In other words, reservations come into existence for all other parties at the moment of the reserving State's signature, ratification or acceptance of the treaty, and before it is operative between State parties. ${ }^{47}$ A textual reading of

40 See (n 33).

41 C Goodman, 'Acta Sunt Servanda? A Regime for Regulating the Unilateral Acts of States at International Law' (2006) 25 AustYBIL 43, 48; Lijnzaad (n 16) 30; A Orakhelashvili, The Interpretation of Acts and Rules in Public International Law (Oxford University Press 2008) 466.

42 ILC 'Report of the Working Group on Unilateral Acts of States' (1997) UN Doc A/CN.4/ L.543.

43 VR Cedeno, Fourth Report on Unilateral Acts of States, UN Doc A/CN.4/519, 24-25, paras $108-109$.

44 Nuclear Tests Case (n 33); Case Concerning the Frontier Dispute (n 33) para 39.

45 Case Concerning the Delimitation of the Continental Shelf between the United Kingdom of Great Britain and Northern Ireland, and the French Republic, United Nations, Reports of International Arbitral Awards, vol XVIII, paras 54-55, at 39-40; Lijnzaad (n 16) 32.

46 G Fitzmaurice, 'The Law and Procedure of the International Court of Justice 1951-4: Treaty Interpretation and other Treaty Points' (1957) 33 BYBIL 203, 230.

47 Coccia (n 19) 26-8; An exception to this principle is elaborated in Effect of Reservations on the Entry into Force of IAmCHR (n 37), where the Inter-American Court of Human Rights came to the conclusion that acceptance of a reservation not prohibited by the Inter-American Convention of Human Rights is not a pre-requisite for entry into force. 
the Vienna Convention supports this observation. The process of entering a reservation is elaborated in Articles 19-21 of the Vienna Convention. Article 19 addresses the circumstances when a reservation may be formulated. ${ }^{48}$ Article 20 provides for the acceptance of or objection to a reservation by an addressee State. ${ }^{49}$ Article 21 of the Vienna Convention addresses the effect of a reservation 'established' in accordance with the articles above. ${ }^{50}$ In such a way, the Vienna Convention expressly distinguishes a reservation 'formulated' (Article 19) and a reservation 'established' (Article 21). ${ }^{51}$ Through Article 19, the Vienna Convention preserves the concept of a sovereign right to formulate (and to withdraw) reservations. ${ }^{52}$ Yet, it makes explicit that a reservation is 'established' not at the time of formulation but at the time of express or tacit acceptance, ie where there is a 'mutuality of consent'. ${ }^{53}$

Secondly, a 'unilateral act' is a legally significant act, a feature which distinguishes a unilateral act from other acts of a 'political' nature. ${ }^{54} \mathrm{~A}$ unilateral act in international law typically 'denotes the creation, modification, suspension, termination, etc., of international rights and obligations', 55 the legal effect of which largely depends on the intention of the State. ${ }^{56}$ In the case Legal Status of Eastern Greenland (Norway $v$ Denmark), the Permanent Court of International Justice (PCIJ) ruled that a declaration made by the Norwegian government was capable of binding itself. ${ }^{57}$ This position was later reaffirmed in the Nuclear Tests Case (New Zealand v France):

48 Art 19, Vienna Convention. $\quad{ }^{49}$ Art 20 ibid. ${ }^{50}$ Art 21 ibid.

51 A Aust, Modern Treaty Law and Practice (Cambridge University Press 2000) 117-18; This observation corresponds to the first limb of the ICJ's Genocide Convention Advisory Opinion, i.e. a State cannot become party to a treaty, if a reservation is incompatible with the object and purpose of the treaty.

52 See ME Villiger, Commentary on the 1969 Vienna Convention on the Law of Treaties (Brill 2009) 262, 268; A Pellet, 'Article 22 ' in O Corten and P Klein (eds), The Vienna Conventions on the Law of Treaties: A Commentary vol 1 (Oxford University Press 2011) 568, 572.

${ }_{53}$ Case concerning the Delimitation of the Continental Shelf between the United Kingdom of Great Britain and Northern Ireland and the French Republic (United Kingdom v France), Decision, 30 June 1977, (1977) 54 ILR 6. In this case, the arbitral panel decided that an objection to a reservation renders a treaty article 'inapplicable as between the two countries to the extent, but only to the extent, of the reservations' as reflected in art 21(3) of the VCLT on the basis of the principle of mutuality of consent. It is well established that in its treaty relations a State cannot be bound without its consent and that consequently no reservation can be effective against any State without its agreement thereto. See Genocide Convention Advisory Opinion (n 2).

54 International law distinguishes between acts that would entail legal consequences and acts that would not. See Nuclear Tests Case (n 33) 267, 'not all unilateral acts imply obligation'; Goodman (n 41) 53.

55 cf Weingerl (n 33) 4.

56 Frontier Dispute Case (n 33) para 39, 'it all depends on the intention of the State in question'. In Nuclear Tests, the ICJ stressed that 'not all unilateral acts imply obligation; but a State may choose to take up a certain position in relation to a particular matter with the intention of being bound - the intention is to be ascertained by interpretation of the act.' Nuclear Tests Case (n 33) 267; Goodman (n 41) 55 .

57 Legal Status of Eastern Greenland, Judgment of 5 April 1933, PCIJ Series A/B No 53, 71. In the case Legal Status of Eastern Greenland, after a series of conversations in which Denmark evinced her willingness to extend political and economic monopoly over Eastern Greenland, 
It is well recognized that declarations made by way of unilateral acts, concerning legal or factual situations, may have the effect of creating legal obligations ... When it is the intention of the State making the declaration that it should become bound according to its terms, that intention confers on the declaration the character of a legal undertaking, the State being thenceforth legally required to follow a course of conduct consistent with the declaration. ${ }^{58}$

Whether there is such an intention is a question of construction. ${ }^{59}$ The standard for finding such intention is nevertheless high as international law does not easily presume restrictions on State sovereignty. ${ }^{60}$ For a unilateral declaration to be binding, the declaration must be "clearly intended to have that effect, and held out ... as an instrument on which others may rely and under which the declarant purports to assume such obligations'. ${ }^{61}$ In case of doubt, a restrictive interpretation is called for such that the consent of the State is not extended. ${ }^{62}$ In Armed Activities on the Territory of the Congo (DRC $v$ Uganda), the ICJ held that a statement by the Justice Minister of Rwanda that the State's reservations on certain provisions of the Genocide Convention would be withdrawn 'shortly' was not specific enough to create legal obligations. ${ }^{63}$

Likewise, reservations too are legally significant acts. ${ }^{64}$ By their very nature, reservations are qualified expressions of consent to be legally bound. ${ }^{65}$

Norway's Minister of Foreign Affairs' reply was that it will 'not make any difficulties' for the Danish government for so doing: 'The Court considers it beyond all dispute that a reply of this nature given by the Minister for Foreign Affairs on behalf of his Government in response to a request by the diplomatic representative of a foreign Power, in regard to a question falling within his province, is binding upon the country to which the Minister belongs.'

${ }_{58}$ Nuclear Tests Case (n 33) para 46.

59 ibid para 43 , 'It is from the actual substance of these statements and the circumstances attending their making, that the legal implications of these acts must be deduced'; Frontier Dispute Case (n 33) para 40, 'in order to assess the intentions of the author of a unilateral act, account must be taken of all the factual circumstances in which the act occurred.'

${ }^{60}$ This position could be traced to the case law of the PCIJ. See SS Lotus (France v Turkey), Judgment of 7 September 1927, PCIJ, Series A No 10, 18; Nuclear Tests Case (n 33) para 47; However, note that the idea which all unilateral acts should be interpreted in a restrictive manner was disagreed by learned scholars. See eg M Fitzmaurice and O Elias, Contemporary Issues in the Law of Treaties (Oxford University Press 2005) 222.

61 See also Nuclear Tests Case (n 33); ILC Draft articles on unilateral acts and commentary thereto, ILC Report 2006, 377, 'A unilateral declaration entails obligations for the formulating State only if it is stated in clear and specific terms. In the case of doubt as to the scope of the obligations resulting from such a declaration, such obligations must be interpreted in a restrictive manner.'

${ }^{62}$ Nuclear Tests Case (n 33) para 47. Nevertheless, in situations where intention is clear, there is no need to resort to a restrictive interpretation. See Phosphates in Morocco (Italy v France) Judgement of 14 June 1938, 1938 PCIJ (Series A/B), No 71, 10, at 23-24.

${ }^{63}$ Armed Activities on the Territory of the Congo (DRC v Uganda), Judgment of 19 December 2005, 2005 ICJ Rep 168.

${ }^{64}$ cf E Csatlós, 'The Legal Regime of Unilateral Act of States' (2010) 7 Miskolc Journal of International Law 33, 56. Csatlós argued that the formulation of a reservation is "not a legal act per se' because the act alone does not create a legal relationship.

${ }^{65}$ In the words of art 20 of the Vienna Convention, a reservation is 'an act expressing a State's consent to be bound by the treaty [subject] to the reservation'. 
Reservations are unilateral statements communicated to the other part(ies), with the intended consequence that legal relationships would be created upon acceptance of the reservation. Moreover, a reservation is communicated at the time of 'signing, ratifying, accepting, approving or acceding to a treaty', 66 ie at the same instance when the reserving State manifests its consent to be bound. In this sense, it is extremely difficult to separate a reservation from the consent that it purports to convey. ${ }^{67}$ It was therefore argued that reservations embody a type of unilateral acts that are 'nonautonomous', ie unilateral acts which operate within a pre-existing legal context (such as a treaty) ${ }^{68}$ or in which their legal effect depends on the corresponding reaction of other States. As Suy commented:

... it is possible that a formally unilateral act must encounter another act of the same quality in order to be capable to produce effects. Taken separately, the two acts have no immediate legal effect as the objective legal order merely attaches potential legal effects to the first act, this is to say only under the condition that the act encounters a corresponding act designated to complete it. As typical example of this phenomenon we can cite offer and acceptance. ${ }^{69}$

The argument in favour of viewing reservations as non-autonomous unilateral acts is therefore that a reservation is the unilateral manifestation of a State's will that is not wholly devoid of legal effect - a reservation produces an intermediate or a 'potential' legal effect. ${ }^{70}$ The intermediate legal effect of such acts is further demonstrated by the requirement that in order to cancel out its intermediate legal effect, a further act of withdrawal is required to be made. ${ }^{71}$ The analogy of offer and acceptance is particularly revealing in the context of reservations in the sense that if the text of a treaty represents the negotiated rights and obligations that were bargained for, a reservation indicates a new offer and would subsequently require a new acceptance by the State to whom the reservation was addressed. This implies that although a reservation is made in the context of a treaty, it is an act separate from the treaty itself.

The above understanding is reflected in the Special Rapporteur Alain Pellet's Third Report to the ILC produced in 1998:

66 Art 19, Vienna Convention.

67 The important role that consent plays in the context of reservations is reflected in the ILC's definition of a reservation in 1962 by Sir Humphrey Waldock, which stipulated that "Reservation" means a unilateral statement whereby a State, when signing, ratifying, acceding to or accepting a treaty, specifies as a condition of its consent to be bound by the treaty a certain term which will vary the legal effect of the treaty in its application between that State and the other party or parties to the treaty.' This definition was subsequently replaced because it was thought that although a reservation accompanies consent to be bound, it is not necessarily the case that the reservation is a condition sine qua non of consent. H Waldock, 'First Report on the Law of Treaties' (1962) 2 UNYBILC 27, 31-2.

68 For a discussion, see ILC 'Summary Record of the 2855th Meeting' (2005) UN Doc A/CN.4/ 2855, paras 30-38, available at <http://legal.un.org/ilc/documentation/english/summary_records/ a_cn4_sr2855.pdf>.

70 Eckart (n 32) 60.

69 E Suy, Actes unilatéraux, 30, cited in Eckart (n 32) 59-60. 
.... The unilateral nature of reservations, as forcefully stated in the first few words of the Vienna definition, is not self-evident. Mr. Brierly, for example, took an entirely contractual approach to the concept of reservations: according to the first Special Rapporteur of the Commission on the law of treaties, a reservation was indissociable from its acceptance and defined by the agreement reached on its content ... This position, which has now been completely abandoned, makes the reservation part of the treaty itself and is incompatible with the legal regime of reservations provided for in the 1969 Vienna Convention, which does not make the validity of a reservation subject to its acceptance by the other parties.

Although a reservation is a unilateral act separate from the treaty, however, it is not an autonomous legal act in that, first of all, it produces its effects only in relation to the treaty to whose provisions it relates and to which its fate is entirely linked and, secondly, its effects depend on the reaction (unilateral as well) or absence of reaction by the other States or international organizations which are parties. From this point of view, it is an 'act condition', an element of a legal relationship that it is not sufficient in itself to create. 'A reservation is a declaration which is external to the text of a treaty. It is unilateral at the time of its formulation; but it produces no legal effects unless it is accepted, in one way or another, by another State.' 'A reservation is a unilateral act at the time it is formulated, but seems to stop being one in its exercise. ${ }^{72}$

Although the passage might not be wholly convincing - whether a contractual approach is adopted depends largely on the design of a treaty - the passage signified a change in how reservations were approached in the works of the ILC. The change in perspective was groundbreaking, but it also left many questions unanswered. For instance, when one views reservations as unilateral acts, do the rules that were originally applicable to reservations thereby change? In particular, does the law on unilateral acts now apply instead of the law of reservations? These questions were addressed in the ILC's Guide to Practice on Reservations to Treaties.

\section{THE APPROACH OF THE ILC'S GUIDE TO PRACTICE ON RESERVATIONS TO TREATIES}

\section{A. The Definition of Reservations in the Guide to Practice}

The unilateral character of reservations is subsequently stressed in the Guide to Practice and its Commentary. Guideline 1.1 of the Guide to Practice on the definition of the reservations largely retains the definitions of reservations laid down in the Vienna Convention. In particular, it defines the understanding of a reservation as a (a) unilateral statement (b) made by a State or international organization either when it expresses consent to be bound by a treaty or it makes a notification of succession to a treaty, and whereby the State or organization (c) purports to modify the legal effects of a treaty. ${ }^{73}$ As addressed above, the idea of unilaterality is reflected in these

\footnotetext{
72 A Pellet, Third Report on Reservations to Treaties, UN Doc A/CN.4/491, paras 120-121.

73 Guideline 1.1, Guide to Practice and Commentary.
} 
elements in the sense that a reservation is a unilateral statement made by a subject of international law without the participation of another. ${ }^{74}$ The making of a reservation only purports to modify the legal effects of a treaty-ie it is a proposal-with its actual effect depending on the response of the addressees.

Guidelines 1.1.1 to 1.1.6 described various types of reservations-namely: statements purporting to limit the obligations of their author; statements purporting to discharge an obligation by equivalent means; reservations relating to the territorial application of the treaty; reservations formulated when extending the territorial application of a treaty; reservations formulated jointly; and reservations formulated by virtue of clauses expressly authorizing the exclusion or the modification of certain provision of the treaty. ${ }^{75} \mathrm{In}$ Guidelines 1.1.1 to 1.1.4 and 1.1.6, the Special Rapporteur carefully inserted the phrase 'unilateral statements' to the descriptions of the varying types of reservations to highlight the fact that each of these reservations are statements unilaterally made. ${ }^{76}$ Guideline 1.1 .5 . on 'reservations formulated jointly' is further indicative of what the ILC refers to as the 'unilateral character' of reservations. It provides that ' $[\mathrm{t}]$ he joint formulation of a reservation by several States or international organization does not affect the unilateral character of that reservation'. ${ }^{77}$ The ILC observes that there are situations where reservations are formulated collectively by multiple States expressing to be bound by a treaty. This occurs typically where States share 'common or similar traditions, interests or ideologies'. ${ }^{78}$ Guideline 1.1.5 is inserted with a view to clarify that even in situations of 'concerted reservations', reservations are still generally considered to have been made unilaterally and individually. This proposal is based partially on practical concerns. For example, in the event where a State wishes to withdraw a jointly formulated reservation, it is unrealistic that the State has to seek the agreement of all other parties that have formulated it. ${ }^{79}$ Conversely, it is uncertain whether a State wishing to accept/object to the reservation would be required to accept/object to the reservation in relation to all other authoring parties. The proposal that joint reservations are made unilaterally and individually is to render the operations of the relevant rules compatible with the principle of res inter alios acta. ${ }^{80}$

\footnotetext{
74 See text accompanying (nn 41-53).

75 For example, in the Guide to Practice and Commentary, 'Statements purporting to discharge an obligation by equivalent means' is referred to as '[a] unilateral statement formulated by a State or an international organization ... by which that State or that organization purports to discharge an obligation pursuant to the treaty in a manner different from, but considered by the author of the statement to be equivalent to that imposed by the treaty' (emphasis added).

76 Similarly, the Working Group made sure that the concept of unilateralism is embedded in the definitions of the various types of interpretive declarations amounting to reservations.

77 Guideline 1.1.5, Guide to Practice and Commentary.

78 Guide to Practice and Commentary (n 11) 53. ${ }^{79}$ ibid 53-5. $\quad{ }^{80}$ Villiger (n 52) 301.
} 


\section{B. Two Stages to Establishing a Reservation}

As demonstrated above, a way to argue that reservations are unilateral acts is to suggest that the Vienna Convention construes the formulation of a reservation by the reserving State and the response of the addressee(s) as two separate acts. ${ }^{81}$ Support for this position could be found in Article 21 of the Vienna Convention which provides that: A reservation established with regard to another party in accordance with Articles 19, 20 and 23:

(a) Modifies for the reserving State in its relations with that other party the provisions of the treaty to which the reservation relates to the extent of the reservation; and

(b) Modifies those provisions to the same extent for that other party in its relations with the reserving State.

2. The reservation does not modify the provisions of the treaty for the other parties to the treaty inter se.

3. When a State objecting to a reservation has not opposed the entry into force of the treaty between itself and the reserving State, the provisions to which the reservation relates do not apply as between the two States to the extent of the reservation. ${ }^{82}$

The chapeau of Article 21(1) of the Vienna Convention suggests that a reservation would entail the effects stated in sub-paragraphs (a) and (b) only if it is 'established $\ldots$ in accordance with Articles 19, 20, and 23'.83 Thus, a reservation could only entail legal effects if it is compatible with the object and purpose of the treaty as prescribed under Article 19 of the Vienna Convention. An impermissible reservation is a priori void at the time of its formulation. ${ }^{84}$ This being the case, it is only logical to think that the legal effect of an impermissible reservation does not depend on the response of the addressee (ie questions regarding the permissibility of a reservation arise before its opposability). ${ }^{85}$ Thus, expressed or tacit acceptances to impermissible reservations are not capable of generating their purported effects (both inter partes and inter se). ${ }^{86}$ Equally, objections to reservations on the basis of impermissibility do not, in the absence of express provisions, necessarily render a reservation illegal: objections are 'probative and not dispositive' ${ }^{87}$

81 See text accompanying (nn 47-53).

82 Art 21, Vienna Convention.

83 Aust (n 51) 129, "The rules in Article 21 on the legal effects of reservations refer to reservations "established" in accordance with Articles 19, 20, 23, and it is hard to see how one could validly establish a reservation when it is prohibited by Article 19.' See RD Kearney and RE Dalton, 'The Treaty on Treaties' (1970) 64 AJIL 495, 512.

84 cf Baratta (n 7) 413, 422, international law is yet 'unable to construct a customary rule identifying invalid reservations to human rights treaties as ineffective acts'.

85 Bowett (n 8); Swaine (n 29) 315.

86 Art 21 of the Vienna Convention provides that a reservation can entail its purported effect only if 'established' in accordance with art 19; B Simma and GI Hernandez, 'Legal Consequences of an Impermissible Reservation to Human Rights Treaty: Where do we Stand?' in E Cannizzaro, The Law of Treaties Beyond the Vienna Convention (Oxford University Press 2011) 60, 62.

87 M Milanovic and L Sicilianos, 'Reservations to Treaties: An Introduction' (2013) 24(4) EJIL 1055. An example of this could be found in Case Concerning Armed Activities on the Territory of 
The above views are reflected in the Guide to Practice which further proposes that the effects of the two unilateral actions - ie the formulation of reservation by the reserving State and the acceptance/objection by the addressee State-are to be considered separately, entailing a clear conceptual separation between the initial status of the reservation and its eventual effects upon acceptance/ objection. ${ }^{88}$ Guideline 4.5 .1 proposes that impermissible reservations are void $a b$ initio: '[a] reservation that does not meet the conditions of formal validity and permissibility set out in Parts 2 and 3 of the Guide to Practice is null and void, and therefore devoid of any legal effect'. ${ }^{89}$ Consequentially, Guideline 4.5.2 provides that ' $[\mathrm{t}]$ he nullity of an invalid reservation does not depend on the objection or the acceptance by a contracting State or a contracting organization'. ${ }^{90}$ Guideline 3.3.3 similarly makes clear that '[a]cceptance of an impermissible reservation by a contracting State or by a contracting organization shall not affect the impermissibility of the reservation'. ${ }^{91}$ In this sense, the effect of an acceptance (or non-objection) is limited in that it only waives the right to object, ${ }^{92}$ thus barring the accepting State from making a claim against the reserving State in the event of a breach. A subsequent acceptance (or non-objection within the period prescribed by a treaty) does not cure the illegality of the reservation nor would an acceptance save its nullity. ${ }^{93}$

The clear emphasis on the initial (il)legality of reservations demonstrated above suggests a more cautious approach to tacit acceptances (ie nonobjections). Under the Vienna Conventions, if a State is unwilling to accept a reservation proposed, it has 12 months to negotiate the amendment or withdrawal of the reservation before either choosing to object to the reservation (to the effect that the reserved provision would not apply to both parties, generating an effect which is identical to that of an acceptance in practice $)^{94}$ or not to enter into treaty relations with the reserving State at

the Congo (New Application: 2002) (Democratic Republic of the Congo v Rwanda), Jurisdiction and Admissibility, Judgment of 3 February 2006, (2006) ICJ Rep 6, para 77, where the DRC alleged that the Rwanda's reservation to the CERD was incompatible with the objects and purpose of the CERD. After concluding that Rwanda's reservation was validly made, the Court remarked specifically that DRC had not objected to Rwanda's reservation at the time it was made. cf J Klabbers, 'Accepting the Unacceptable? A New Nordic Approach to Reservations to Multilateral Treaties' (2000) 69 NordicJInt'lL 179.

${ }^{88}$ See eg Guidelines 1.1.1 to 1.1.6 and 1.3.3 on the formulation of reservations (and 2.1.5 on the communication of reservations); Guidelines 2.6 to 2.6 .12 on the objections to a reservation and Guidelines 2.8 to 2.8 .12 on the acceptance of reservations; Swaine (n 29) 314-17.

${ }_{99}$ Guideline 4.5.1., Guide to Practice and Commentary. $\quad 90$ ibid 4.5.2. $\quad 91$ ibid 3.3.3.

92 Coccia (n 19) 33-4; Lijnzaad (n 16) 96.

93 cf Swaine (n 29) 307, 317; see ILC, Report on State Responsibility, Report of the ILC on the UN General Assembly, Draft Articles on State Responsibility [1979] 2 UNYBILC 113, 'there is no doubt that if the consent is given only after the commission of the act (ex post facto), it will simply amount to a waiver of the right to assert responsibility and the claims arising therefrom. But, with such a waiver, the wrongfulness of the prior act remains.'

94 JM Ruda, 'Reservations to Treaties' (1975-III) 146 Hague Academy of International Law, Collected Courses 95, 200, 'ultimately the legal effects of an objection and an acceptance of a 
all. ${ }^{95}$ If the addressee State does not object in time, the reserving State is entitled to rely on the addressee's silence, ${ }^{96}$ thereby honouring the reserving State's legitimate expectation and providing a level of certainty for the reserving State to conduct its affairs. Nevertheless, this arrangement only makes sense in cases where the treaty exchanges substantive interState rights and interests, and hardly makes sense for treaties of a nonreciprocal nature, ${ }^{97}$ largely owing to a lack of incentives. ${ }^{98}$ Moreover, the failure to object may also be a result of the fact that some reservations are drafted in a manner that is abstract such that their effects are difficult to ascertain in the absence of an actual situation. ${ }^{99}$ Thus, if tacit acceptance is to be construed, in theory, as an implied consent to the permissibility of the reservation, at issue is the quality of that consent. As the Human Rights Committee (HRC) identified, where treaty obligations do not relate to reciprocal interests, 'it is not safe to assume that a non-objecting State thinks that a particular reservation is acceptable'. ${ }^{100}$

\section{The Competence of Treaty-Monitoring Bodies}

Since a reservation comes into existence prior to the acceptance of contracting parties (as noted in section B above) and thus before it is operative as between

reservation are identical, when the treaty remains in force between the objecting and reserving States'; see Guide to Practice and Commentary (n 11) 288.

95 Art 20(4)(b), Vienna Convention.

96 Art 20(5) ibid.

97 Genocide Convention Advisory Opinion (n 2) 23; See eg France, Norway, Denmark, Sweden, Netherlands v Turkey, ECommHR, Decision No 9942/82, para 39, 'The Commission finds that the general principle of reciprocity in international law and the rule, stated in Article 21, para.1 of the Vienna Convention on the Law of Treaties, concerning bilateral relations under a multilateral treaty do not apply to the obligations under the European Convention on Human Rights, which are "essentially of an objective character, being designed rather to protect the fundamental rights of individual human beings from infringement by any of the High Contracting Parties than to create subjective and reciprocal rights for the High Contracting Parties".'

98 HJ Bourguignon, 'The Belilos Case: New Light on Reservations to Multilateral Treaties' (1989) 29 VaJInt'lL 347, 369. Moreover, States may wish to avoid offending parties that have political and economic ties. They may also wish to 'avoid having scrutiny directed back at themselves'. EF Sherman, Jr., 'The US Death Penalty Reservation to the International Covenant on Civil and Political Rights: Exposing the Limitations of the Flexible System Governing Treaty Formation' (1994) 29 TexInt'ILJ 69, 81.

99 Other examples include a general reservation made by the US to the Genocide Convention which stated that "nothing in the Convention requires or authorises legislation or other action by the United States of America prohibited by the Constitution of the United States as interpreted by the United States'. Assessment of the reservation seems to require extensive knowledge on US Constitutional Law. Furthermore, it seems to require addressee States to pre-empt every situation which may fall within the scope of the reservation in order to object to it. See Aust (n 51) 120-1; Swaine (n 29) 318; I Sinclair, The Vienna Convention on the Law of Treaties (2nd edn, Manchester University Press 1984) ch 3, 63; DL Hylton, 'Default Breakdown: The Vienna Convention on the Law of Treaties: Inadequate Framework on Reservations', (1994) 27 VandJTransnat'lL 419, 439.

${ }^{100}$ HRC General Comment No 24, 'General Comment on Issues Relating to Reservations made upon Ratification or Accession to the Convention or the Optional Protocols thereto, or in relation to declarations under Article 41 of the Covenant' UN Doc CCPR/C/21/Rev.1/Ad.6 (1994) para 17 (HRC General Comment No 24). 
parties, the timing of a reservation a priori implies that the legality of a reservation would come into question before acceptance (express or tacit). Thus, where the permissibility of a reservation is in doubt, the effect of the reservation is a question that should be reserved for a competent judicial/ quasi-judicial body where such mechanism is available and where a treaty does not indicate that contracting States are the sole assessors of compatibility. ${ }^{101}$

In the past, the competence of treaty-monitoring bodies to scrutinize reservations has been objected to by proponents of the opposability school, largely because the Vienna Conventions is silent in this aspect. Nevertheless, international jurisprudence dating back to the PCIJ seems clear to the extent that 'as a general rule, any body possessing jurisdictional power has the right in the first place to itself determine the extent of its jurisdiction'. ${ }^{102}$ In the Nottebohm Case (Preliminary Objection) (1953), the ICJ remarked that:

Since the Alabama case, it has been generally recognized that following the earlier precedents, that, in the absence of any agreement to the contrary, an international tribunal has the right to decide as to its own jurisdiction and has the power to interpret for this purpose the instruments which govern that jurisdiction. ${ }^{103}$

In this context, it seems reasonably clear that ascertaining the permissibility and applicability of a reservation is also integral to the competence that is endowed by treaties establishing human rights monitoring bodies. Similar logic transpired in HRC's General Comment No 24:

It necessarily falls to the Committee to determine whether a specific reservation is compatible with the object and purpose of the Covenant. This is in part because ... it is a task that the Committee cannot avoid in the performance of its functions. In order to know the scope of its duty to examine a State's compliance under article 40 or a communication under the first Optional Protocol, the Committee has necessarily to take a view on the compatibility of a reservation with the object and purpose of the Covenant and with general international law. ${ }^{104}$

Yet, what remained at doubt, as Baratta observed, is the difference between the competence to ascertain the legality of a reservation and the competence to

101 See eg art 20(2) of the UN Convention on the Elimination of All Forms of Racial Discrimination (adopted 21 December 1965, entered into force 4 January 1969) 660 UNTS 195, providing, inter alia, that, '[a] reservation shall be considered incompatible or inhibitive if at least two thirds of the States Parties objection to it'.

102 Interpretation of the Greco-Turkish Agreement of December 1st, 1926, (1928) PCIJ Series B, No 16, 20.

${ }^{103}$ Nottebohm Case (Preliminary Objections) [1952] ICJ Rep 111, 119. The quoted passage refers specifically to art 36(6) of the Statute of the ICJ, 'In the event of a dispute as to whether the Court has jurisdiction, the matter shall be settled by the decision of the Court.'

104 HRC General Comment No 24, para 20; note, however, that other treaty bodies have taken a more reserved stance on this issue. See 'The Practice of Human Rights Treaty Bodies with Respect to Reservations to International Human Rights Treaties' UN Doc HRI/MC/2005/5 (13 June 2005). 
pronounce on the effects of such reservations. ${ }^{105}$ In other words, the creation of treaty-bodies does not render treaty-bodies 'supranational'. ${ }^{106}$

The ILC takes a clear position supporting the competence of these bodies to assess reservations, but it also makes clear that views of the treaty-bodies are non-legally binding. Guideline 3.2 provides that contracting States or organizations, dispute settlement bodies, and treaty monitoring bodies have the competence to assess the permissibility of reservations. ${ }^{107}$ Guideline 3.2.5 further provides that where a dispute settlement body is competent to decide upon the permissibility of the reservation, such determination is binding on parties. This is to be contrasted with Guidelines 3.2.1 and 3.2.3; the former provides that a treaty-monitoring body has the competence to assess permissibility, and the latter provides that States 'shall give consideration to [the treaty monitoring body's] assessment of the permissibility' (emphasis added). ${ }^{108}$ The position of the ILC is in line with prevailing case law ${ }^{109}$ and views of treaty bodies. ${ }^{110}$

\section{The Emphasis on Intention and Implications for Severability}

Although an impermissible reservation may be void ab initio and thus, according to Guideline 4.5.1, 'devoid of any legal effect', an impermissible reservation may still be legally significant as far as the consent of the reserving State is concerned. A very relevant question is whether a State's consent to be legally bound by a treaty is vitiated when a reservation is subsequently found to be impermissible.

When reservations are understood in light of their unilateral character, it becomes reasonably clear that what determines severability is the intention of the reserving State. As analogy, we may refer to judicial interpretations on reservations to declarations of acceptances to the compulsory jurisdiction of the ICJ pursuant to Article 36 of the ICJ Statute. Conventionally, rules applicable to reservations to declarations of acceptances may not be transposable to reservations to treaties because, unlike treaties, a declaration of acceptance is a unilateral act stricto sensu. ${ }^{111}$ Declarations of acceptances

\footnotetext{
105 Baratta (n 7) 416; cf Aust (n 51) 123.
}

106 See Pellet (n 6) 405, 422; For example Imbert, argued that the European Commission on Human Rights and the ECtHR do not have the jurisdiction to declare reservations invalid. P-H Imbert, Les réserves aux traités multilatéraux (Pédone 1978).

107 Guideline 3.2, Guide to Practice. $\quad{ }^{108}$ Guideline 3.2.1, Guide to Practice.

109 See Temeltasch v Switzerland (1982) DR 31, 120, 145, para 65; Belilos v Switzerland [1988] ECHR 4. Here, the ECtHR invoked arts 19 (providing that the Court was established to ensure observance of the engagements undertaken by States to the Convention), 45 (providing that the Court has jurisdiction over the interpretation and application of the Convention) and 49 (providing the Court has jurisdiction to determine its own jurisdiction), to establish its competence in assessing permissibility. In Loizidou, art 19 of the ECHR was invoked in a similar manner to establish competence. Loizidou v Turkey [1995] ECHR 10.

110 HRC General Comment No 24, para 18.

111 Fisheries Jurisdiction (Spain v Canada) Jurisdiction of the Court (1952) ICJ Rep 454 (Fisheries Jurisdiction) para 46, a declaration of acceptance is 'a unilateral act of State sovereignty'. 
'are facultative, unilateral engagements that States are absolutely free to make or not to make ... [and are] equally free either to do so unconditionally and without limit of time for its duration, or to qualify it with conditions or reservations'. ${ }^{112}$ Rules may only apply analogously to the extent that they are compatible with the character of these instruments. ${ }^{113}$ Yet, if one stresses the unilateral element of reservations to treaties, especially when one makes the distinction between a reservation in its initial phase (as a proposal) with a reservation later 'established' upon its acceptance, ${ }^{114}$ the unilateral proposal acquires a nature very similar to that of a reservation attached to a unilateral declaration: they are both unilateral manifestations of will and the formulation of which other States do not participate. ${ }^{115}$

In the Case of Certain Norwegian Loans, at issue was whether Norway was entitled to rely on France's reservation on the declaration of acceptance of the Court's jurisdiction. ${ }^{116}$ Sir Hersch Lauterpacht in his Separate Opinions decided that the French reservation was invalid; yet, rather than severing the invalid reservation from the Declaration, he came to the conclusion that the invalid reservation rendered the acceptance of the Court's jurisdiction invalid $a b$ initio. He reasoned that:

... it is not open to the Court in the present case to sever the invalid condition from the Acceptance as a whole. For the principle of severance applies only to provisions and conditions which are not of the essence of the undertaking. Now an examination of the history of this particular form of the reservation of national jurisdiction shows that the unilateral right of determining whether the dispute is essentially within domestic jurisdiction has been regarded by the declaring State as one of the crucial limitations - perhaps the crucial limitation - of the obligation undertaken by the acceptance of the Optional Clause of Article 36 of the Statute. ${ }^{117}$

In other words, the crucial factor is whether, from the declaring State's point of view, the reservation is an essential one-one that constitutes a condition sine qua non.

Lauterpacht further clarified his position in the Interhandel Case (Switzerland $v$ US), which concerned a reservation to the Declaration of

112 Declarations of acceptance of the compulsory jurisdiction of the Court (Military and Paramilitary Activities in and against Nicaragua (Nicaragua v United States of America)), Jurisdiction and Admissibility, Judgment, (1984) ICJ Rep 418, para 59.

113 Fisheries Jurisdiction (n 111) para 46. 114 ibid.

115 This view was adopted by the ILC in its Commentary on the Guide to Practice: 'The Commission is aware that the statements in question are of a different nature from those of reservations and declarations. Formulated unilaterally in connection with a treaty text, they nonetheless have important common features, and it would seem necessary to take account of the Court's warning in interpreting unilateral statements made by a State or an international organization in connection with a treaty with a view to determining its legal nature.'

116 Case of Certain Norwegian Loans [1957] ICJ Rep 9, Separate Opinion of Judge Sir Hersch Lauterpacht (Norwegian Loans Case).

117 ibid 56. 
Acceptance by the US framed in identical wordings to the French Government's declaration in the Norwegian Loans Case:

[A] condition which, having regard to the intention of the party making it, is
essential to and goes to the root of the main obligation cannot be separated
from it ... A party cannot be held to be bound by an obligation divested of a
condition without which that obligation would never have been undertaken ....
If that reservation is an essential condition of Acceptance in the sense that without
it the declaring State would have been wholly unwilling to undertake the principal
obligation, then it is not open to the Court to disregard that reservation and at the
same time to hold the accepting State bound by the Declaration. ${ }^{118}$

The view that a reservation incompatible with the object and purpose of a treaty may be relied upon to escape the binding effects of a treaty was in the past contested by commentators who saw no reason why a reserving State should benefit from an impermissible reservation ex injuria non oritur ius. ${ }^{119}$ Nevertheless, in order for the maxim to apply, it would seem that a level of mala fides is required to be presumed, ${ }^{120}$ a motive that is almost impossible to determine. ${ }^{121}$

Subsequent case law and views that argued strongly in favour of severability reasoned instead that severability should only be a presumption. These contentions-including, most notably, the series of European Court of Human Rights (ECtHR) cases that formed the basis of the 'Strasbourg approach' as well as Human Rights Committee's General Comment No $24-$ did not go so far as to disregard the intention of the reserving State. ${ }^{122}$

118 Interhandel Case (Switzerland v US) [1959] ICJ Rep 6, 77-78, 93. The case concerned the interpretation of the US declaration accepting the compulsory jurisdiction of the ICJ. The declaration was drafted to the effect that it subjected the ICJ's jurisdiction to the right of the State 'to determine in each case the existence of the obligation to resort to judicial or arbitral settlement'. President Klaestad and Judge Armand-Ugon, upon deciding that the reservation was invalid, reflected upon the true intention of the reserving State in considering the legal consequences of the invalid reservation. Both judges thought that the US reservation was invalid but severable. For an analysis, see Bourguignon (n 98); Goodman (n 41) 532.

119 See eg Lijnzaad (n 16) 55.

120 Simma and Hernandez (n 86) 84.

121 Moreover, there are multiple reasons why a State entered a reservation that is incompatible with the object and purpose of the treaty, including inadvertent miscalculations, given that the object and purpose of a treaty is often difficult to ascertain. For a detailed explanation on the difficulties in ascertaining the object and purpose of a treaty, see eg I Buffard and K Zemanek, 'The "Object and Purpose" of a Treaty: An Enigma?' (1998) 3 Austrian Review of International \& European Law 311; DS Jonas and TN Saunders, 'The Object and Purpose of a Treaty: Three Interpretive Methods' (2010) 43(4) VandJTransnat'lL 565; Furthermore, a reservation may be rendered impermissible owing to the evolving development of a jus cogens norm. See U Linderfalk, 'Reservations to Treaties and Norms of Jus Cogens: A Comment on Human Rights Committee General Comment No. 24' in I Ziemele (ed), Reservations to Human Rights Treaties and the Vienna Convention Regime: Conflict, Harmony and Reconciliation (Martinus Nijhoff Publishers 2004) 213; LJ LeBlanc, 'Reservations to the Convention on the Rights of the Child: A Macroscopic View of State Practice' (1996) 4 Int'1JChildRts 357, 378-9.

${ }^{122}$ This should be contrasted with State practices, including a considerable number of Nordic States, which aim at objecting to a reservation that they deem incompatible with the object and purpose of the treaty, yet considering reserving States bound by the treaty (thereby achieving a 
Instead, the presumption of severability is based on the apparent contradiction that a State expressing itself to be bound by a treaty would defeat its own consent by entering a reservation that is impermissible (ie a reservation is presumed to have been made in good faith), ${ }^{123}$ or that the reserving State, fully knowing the potential consequences of impermissible reservations, ran the risk of nevertheless formulating a broad reservation that might defeat the object and purpose of the treaty (thus implicitly consenting to be bound without the benefit of the reservation should it be found impermissible). ${ }^{124}$

In Belilos $v$ Switzerland, upon ruling that the Swiss interpretative declaration' amounted to a reservation that is invalid, the ECtHR decided that 'it is beyond doubt that Switzerland is, and regards itself as, bounded by the Convention irrespective of the validity of the declaration' (emphasis added). ${ }^{125}$ This approach was followed in Weber $v$ Switzerland. ${ }^{126}$ In Loizdou v Turkey, the ECtHR noted that despite earlier case law which ruled that reservations on the relevant articles may be severed, Turkey went on to file declarations in respect of the same articles. This 'indicates a willingness on [the State's] part to run the risk' that such declarations, which are in fact reservations, may be severed. ${ }^{127}$

The HRC's General Comment No 24 is often regarded as having made one of the most progressive statements in favour of severability. ${ }^{128}$ It noted that:

The normal consequence of an unacceptable reservation is not that the Covenant will not be in effect at all for a reserving party. Rather, such a reservation will generally be severable, in the sense that the Covenant will be operative for the reserving party without benefit of the reservation. ${ }^{129}$

Nevertheless, the position that severance is to be considered the 'normal consequence' was later clarified in Rawle Kennedy $v$ Trinidad and Tobago:

Suffice it to say that even in dealing with reservations to the Covenant itself the Committee did not take the view that in every case an unacceptable reservation

'super-maximum effect'). See M Scheinin, 'Reservations to the International Covenant on Civil and Political Rights and its Optional Protocols - Reflections on State Practice' $<$ http://www.nuigalway. $\mathrm{ie} /$ sites/eu-china-humanrights/seminars/ds0411i/martin\%20scheinin-eng.doc $>$; see also Klabbers (n 87).

${ }^{123}$ Bowett (n 8) 75-6, 'In principle, the will which ought to prevail is the will to accept the treaty'; WA Schabas, 'Reservations to the Convention on the Elimination of All Forms of Discrimination against Women and the Convention on the Rights of the Child' (1997) 3 William \& Mary Journal of Women and the Law 79, 109; Simma and Hernandez (n 86) 82; Lijnzaad (n 16) 57, 58. When viewed as a unilateral act, judicial support for this position could further be found in Nuclear Test case, '[j] ust as the very rule of pacta sunt servanda in the law of treaties is based on good faith, so also is the binding character of an international obligation assumed by unilateral declaration'. See Nuclear Test Case (n 33) para 49.

124 Loizidou v Turkey [1995] ECHR 10, Preliminary Objections, para 95.

125 Belilos v Switzerland [1988] ECHR 4, para 60. ${ }^{126}$ Weber v Switzerland [1990] ECHR 13.

127 Loizidou v Turkey [1995] ECHR 10, Preliminary Objections, para 95.

128 For an analysis on the legal precedents and justification of HRC's General Comment No 24, see EA Baylis, 'General Comment 24: Confronting the Problem of Reservations to Human Rights Treaties' (1999) 17(2) BerkeleyJInt’IL 277.

129 HRC General Comment No 24, para 18. 
will fall aside, leaving the reserving state to become a party to the Covenant without benefit of the reservation. As can be seen from the section of General Comment no. $24 \ldots$ the Committee merely stated that this would normally be the case. The normal assumption will be that the ratification or accession is not dependent on the acceptability of the reservation and that the unacceptability of the reservation will not vitiate the reserving state's agreement to be a party to the Covenant. However, this assumption cannot apply when it is abundantly clear that the reserving state's agreement to becoming a party to the Covenant is dependent on the acceptability of the reservation. The same applies with reservations to the Optional Protocol. ${ }^{130}$

In other words, severance as a 'normal consequence' is only a presumption, which could be rebutted upon showing that the State did not, at the time of expressing to be bound, intend to become party without the benefit of the reservation.

The above line of reasoning, therefore, indicated that the effect of an impermissible reservation depends primarily on the intention of the reserving State. Guideline 4.5.3 incorporates the above ideas:

1.) The status of the author of an invalid reservation in relation to a treaty depends on the intention expressed by the reserving State or international organization on whether it intends to be bound by the treaty without the benefit of the reservation or whether it considers that it is not bound by the treaty.

2.) Unless the author of the invalid reservation has expressed a contrary intention or such an intention is otherwise established, it is considered a contracting State or a contracting organization without the benefit of the reservation.

3.) Notwithstanding paragraphs 1 and 2, the author of the invalid reservation may express at any time its intention not to be bound by the treaty without the benefit of the reservation.

4.) If a treaty monitoring body expresses the view that a reservation is invalid and the reserving State or international organization intends not to be bound by the treaty without the benefit of the reservation, it should express its intention to that effect within a period of twelve months from the date at which the treaty monitoring body made its assessment. ${ }^{131}$

As can be seen, while sub-paragraph 1 lays down the determining factor for assessing severability (ie intention of the reserving State), sub-paragraph 2 establishes a presumption of severability. Meanwhile, sub-paragraph 4 is clearly recommendatory in nature, ${ }^{132}$ and could not easily be reconciled with

\footnotetext{
${ }^{130}$ Rawle Kennedy v Trinidad and Tobago, UN Doc CCPR/C/57/D/845/1999 (31 December 1999) (emphasis original).

131 Guideline 4.5.3, Guide to Practice.

132 The Guide to Practice and Commentary distinguishes a range of categories of the guidelines covering 'a wide range of obligatoriness and have very different legal values', one of which is a
} 
earlier case law and other Guidelines which propose that the consent of a State to be bound without the benefit of the reservation is to be ascertained at the time of consent. ${ }^{133}$ The recommendatory nature of the sub-paragraph is also reflected in the inherently vague words 'it should express its intention'. Nevertheless, subparagraph 4 only applies to treaty monitoring bodies, the decisions and concluding observations of which are generally considered non-legally binding; as noted above, decisions of dispute settlement bodies on permissibility would have had a binding effect on the reserving State. Prima facie, the proposal in sub-paragraph 4 intends to strike a balance between reserving States' continuing participation of (predominantly) human rights treaties (ie to avoid denunciation), and at the same time avoid the consequence where a State is able to rely on an incompatible reservation as if the reservation were valid, which may result in undermining the integrity of the treaty. It is contended that sub-paragraph 4 is a more nuanced approach to the current state of affairs. Even where external aides are available in interpreting reservations (as shall be explained below), ascertaining the intention of a State is not always an easy task. ${ }^{134}$ Moreover, this approach avoided thwarting existing constructive dialogues between treaty bodies and reserving States in persuading the latter to withdraw impermissible reservations. ${ }^{135}$

From a broader perspective, the overall approach of the ILC on the issue of severability has far-reaching implications to the practice of reservations. First, the approach promotes greater responsibility and readjusts the imbalance that is conventionally thought to favour the reserving State. ${ }^{136}$ It has been argued that the conventional Vienna regime 'give[s] an unacceptable advantage to a reserving state' 137 in the sense that the reserving State may formulate wide reservations without consequences: ie when a reservation is incompatible with the object and purpose of a treaty, the State cannot be bound by the treaty without the benefit of the reservation since it cannot be bound by obligations without its consent; and when the reservation is compatible with the object and purpose of the treaty, the reservation will operate with intended effects 'to the extent of the reservation' whether it is accepted or objected.

The presumption of severability alters that imbalance and heightens the stakes for the reserving State. Where a reserving State has the genuine intention to become party to a treaty, the onus now falls squarely on that State to ensure that its reservations are compatible. The reserving State may not be able to rely on the uncertainty that pertains to the relevant rules under the Vienna Conventions, according to which the addressee's silence within

category of guidelines which are 'simply recommendations and are meant only to encourage'. See Introduction, Guide to Practice and Commentary. $\quad{ }^{133}$ See text accompanying (nn 122-127).

134 Buffard and Zemanek (n 121).

136 DW Greig, 'Reciprocity, Proportionality, and the Law of Treaties' (1994) 34 VaJInt'lL 295, 328 , noting that the Vienna Convention 'give[s] an unacceptable advantage to a reserving state'.

${ }^{137}$ See eg Klabbers (n 87). 
12 months may be deemed acceptance of the reservations' validity. This approach would also promote a more cautious attitude towards reservations drafting and encourages reservations that are less vague and less aggressive.

Second, the approach promotes predictability in several ways. For instance, the effects of reservations are more readily ascertainable when reserving States are less inclined to formulate vague reservations. Moreover, from the perspective of the reserving party, the consequence of invalid reservations is rendered more predictable, as the reserving party is encouraged to make its intention known. In such a way, the approach provided by the Guide to Practice also better preserves the consent of both parties. Where the scope and effect of reservations are more predictable, the addressee State is in a better position to assess whether to accept or object a reservation. In this context, it is safer to assume that a non-objection should mean tacit acceptance. For the reserving State, the fact that it would be required to give more thought before entering into treaty relations arguably improves the quality of consent and would arguably increase its willingness to comply with the terms of the treaty. Consent is also better preserved as the reserving State knows ex ante the potential consequences of impermissibility. ${ }^{138}$

Third, this approach brings greater coherence to the law on reservations. In particular, it narrows the gap that was thought to exist between 'contract treaties' and those treaties that cannot, strictly speaking, be reduced to pairs of bilateral relations. A typical example of the latter includes human rights treaties. Since obligations pertaining to human rights treaties are articulated for the benefit of individuals in the contracting State and in most cases do not translate into substantial rights and benefits for other State parties, ${ }^{139}$ there is consequently little incentive for States to scrutinize reservations, ${ }^{140}$ and

138 In addition, Simma and Hernandez eloquently observe that:

A presumption of severability finds its root in the consent of states taken as a whole. Because a reservation incompatible with the object and purpose of a human rights treaty would, if successful, ipso facto, constitute a fundamental change to the treaty, it follows logically that the ability of states to restrict the scope of their consent relating to the core purposes of the treaty would do violence to the consent of all other state parties. As recognized in the Advisory Opinion on Reservations to the Genocide Convention '[i]t is well established that in its treaty relations a State cannot be bound without its consent. [...] none of the contracting parties is entitled to frustrate or impair, by means of unilateral decisions or particular agreements, the purpose and raison d'etre of the convention'... a presumption of severability... removes human rights instruments from the grip of the bilateral paradigm and places them into an objective but equally, consensualist, framework.

Simma and Hernandez (n 86) 81.

139 B Simma, 'From Bilateralism to Community Interest in International Law' (1994) 250 Recueil des Cours de l'Académie de Droit International 217, 296-7. See also HRC General Comment No 24, para 17. Note, however, that the lack of reciprocity does not apply to all human rights treaties nor all human rights obligations. A notable exception would be the minority treaties concluded during the times of the League of Nations. Another example is where there could in fact be reciprocity concerns the extraterritorial application of human rights treaties.

140 Some States may even consider such reviews as hostile acts. 
objections to reservations remain scarce. ${ }^{141}$ The Guide to Practice introduces crucial safeguards in this respect by first arguing that reservations are partly unilateral acts, then affirming the competence of monitoring bodies in scrutinizing reservations, and subsequently introducing the presumption of severability. Moreover, it achieves the above by providing a solid doctrinal basis for these positions without having to establish a 'special regime' for human rights treaties. ${ }^{142}$

Thus, the arrangement under the Guide to Practice has the potential to lead to a more coherent theory and practice on reservations while striking a delicate balance between the need to take into account the consent of both the reserving and the non-reserving States, especially in contexts of normative or human rights treaties, where ' $[\mathrm{t}]$ he usefulness of objections ... has been repeatedly questioned'. ${ }^{143}$

\section{E. Unilaterality and the Interpretation of Reservations}

Interpretations of reservations occur in multiple stages of adjudication: to determine whether a unilateral statement should be construed as a interpretative declaration or a reservation; to determine the compatibility of the reservation to the object and purpose of the treaty; to ascertain the exact scope of the reservation and its effects; and to determine the effect/ consequences of a reservation where the reservation is invalid. Given the importance of interpreting reservations, rules in this respect are surprisingly unclear. If reservations are to be construed as (non-autonomous) unilateral acts, the question ought to be asked whether rules concerning the interpretation of treaties or rules concerning the interpretation of unilateral acts should apply in interpreting reservations.

A major difference between the law of treaties and the law of unilateral acts concern their interpretation, which naturally arises as a result of the fact that treaty provisions are negotiated texts and unilateral statements are not. The aim of interpreting treaty provisions is, in principle, ${ }^{144}$ to give effect to the common intention of the parties as to the rights and obligations agreed in the

141 Lijnzaad (n 16) 6; A Seibert-Fohr, 'The Potentials of the Vienna Convention on the Law of Treaties with Respect to Reservations to Human Rights Treaties' in Ziemele, Reservations to Human Rights Treaties and the Vienna Convention Regime: Conflict Harmony or Reconciliation (n 121) 183, 194.

142 For an excellent account of the arguments in favour of a special regime, see eg K Korkelia, 'New Challenges to the Regime of Reservations under the International Covenant of Civil and Political Rights' (2002) 13 EJIL 437.

143 Seibert-Fohr (n 141).

144 The purpose of interpretation varies slightly with different school of thoughts, including textualists, subjectivists and teleologists. For an overview see eg ME Villiger, 'The Rules on Interpretation: Misgivings, Misunderstandings, Miscarriage? The "Crucible" Intended by the International Law Commission' in Cannizzaro, The Law of Treaties Beyond the Vienna Convention (n 86) 105-22. 
negotiated text. ${ }^{145}$ For instance, in Land and Maritime Boundary between Cameroon and Nigeria, the ICJ pronounced that a treaty provision must be interpreted in accordance 'with the intention of the parties at the time'. ${ }^{146}$

When it comes to the interpretation of a unilateral statement, emphasis is placed on the intention of the author State. The emphasis on the author's intention was stressed in the Anglo-Iranian Oil Co (Preliminary Objections), whereby the Court acknowledged the particular way in which Iran's declaration was phrased as 'a decisive confirmation of the intention of the Government of Iran at the time when it accepted the compulsory jurisdiction of the Court'. ${ }^{147}$ This approach was followed in the Fisheries Jurisdiction (Spain v Canada) Jurisdiction of the Court, in which the ICJ placed emphasis on the intention of the reserving State as one of the main criteria for interpreting the reservation attached to a declaration on the jurisdiction of the court: ' ... since a declaration under article 36, paragraph 2, of the Statute is a unilaterally drafted instrument, the Court has not hesitated to place a certain emphasis on the intention of the depositing State'. ${ }^{148}$ The emphasis on the intention of the author, although it may be criticized for its apparent disregard for the expectations and reliance of the addressees, is consistent with the principle that restrictions on State sovereignty should not be implied lightly. ${ }^{149}$

Nevertheless, like interpretations of treaty provisions, the text of the statement remains the main reliable source upon which intention is construed. In The Legal Status of Eastern Greenland, the PCIJ sought to determine the legal effects of a declaration upon 'a careful examination of the words used'. ${ }^{150}$ In other words, what remained relevant was the manifest intention of the reserving State at the time when the reservation was formulated. The same is provided in existing case law on the interpretation of treaty reservations. In Boyce et al. v Barbados before the Inter-American Court of Human Rights (IAmCHR), the IAmCHR was confronted with the question whether a reservation submitted by Barbados at the time it ratified the InterAmerican Convention on Human Rights prevented the Court from deciding

145 Brownlie (n 14) 631; The tension between textual interpretations and approaches which seek to honour the intention of parties reflect what Koskenniemi's describes as an 'oscillation between subject and approaches' in many aspects of international legal theory. Nevertheless, McNair eloquently summarized that crucial to all interpretative work in existing practice is to give effect to the manifest intention of the parties 'expressed in the words used by them in the light of the surrounding circumstances'; see MA Koskenniemi, 'Theory: Implications for the Practitioner' in P Allot et al. (eds), Theory and International Law: An Introduction (BIICL 1991) 3-45; McNair, Law of Treaties (n 33) 365-6; PM Dupuy, 'Evolutionary Interpretation of Treaties: Between Memory and Prophecy' in Cannizzaro, The Law of Treaties Beyond the Vienna Convention (n 86) 123, 126-31; For more on intent, see J Klabbers, The Concept of Treaty in International Law (Kluwer Law International, 1996) 65-95.

146 Land and Maritime Boundary between Cameroon and Nigeria (2002) ICJ Rep 303 para 59.

147 Anglo-Iranian Oil Co Primary Objection, Judgment, (1952) ICJ Rep 107.

148 Fisheries Jurisdiction (n 111) paras 48 and 49. 69.

150 Legal Status of Eastern Greenland (Denmarkv Norway) (1933) PCIJ (ser.A/B) No 53 (Apr 5 ) 
issues concerning capital punishments. The Court made it clear that in interpreting reservations[,] the Court must first and foremost rely on a strictly textual analysis'. ${ }^{151}$ In the Restrictions on Death Penalty advisory opinion, the IAmCHR remarked that, 'without excluding the possibility that supplementary means of interpretation might, in exceptional circumstances, be resorted to, the interpretation of reservations must be guided by the primacy of the text'. ${ }^{152}$ In other words, intention is inferred from the 'objective or objectively verifiable factors, such as the content of the statement and its communication to the addressees, in terms of the literal meaning of the words used'. ${ }^{153}$

Unlike treaty interpretation, however, evidence admissible to support the interpretation of unilateral statements is arguably more relaxed, and includes, for instance, materials that would shed light on the circumstances pertaining the reserving State when the reservation was made, ${ }^{154}$ including the travaux préparatoires of the ratification process, ${ }^{155}$ as well as internal sources regarding the preparation of the reservation, ${ }^{156}$ such as the relevant legislative proposals, press communiqué, parliamentary debate, and ministerial statements. ${ }^{157}$ Thus, in Anglo-Iranian Oil Co., the ICJ acknowledged that an Iranian law approving the declaration to accept the compulsory jurisdiction of the Court was relevant to ascertaining the intention of the Iranian government at the time it ratified the declaration. ${ }^{158}$ Interestingly, case law seems to support the same approach to be applied to reservations to treaties. In Weber $v$ Switzerland, the ECtHR decided that ' $[\mathrm{t}]$ he concepts in a reservation should be understood with reference to the domestic law of the State which made it'. ${ }^{159}$ Moreover, in interpreting a reservation, intention of the author ought to be ascertained at the time of expression of consent not after. ${ }^{160}$ This view is in line with earlier ICJ jurisprudence in the Fisheries Jurisdiction (Spain v Canada), when the Court was tasked to interpret a reservation attached to a declaration of the Court's jurisdiction. It held: 'The Court will thus interpret the relevant words of a declaration including a reservation contained therein in a natural and

151 Boyce et al. v Barbados, Inter-AmCtHR (Ser. C) No 169 (2007) para 15.

152 Restrictions to the Death Penalty (Arts 4(2) and 4(4) of the American Convention on Human Rights), Advisory Opinion OC-3/83, 8 September 1983, Inter-AmCtHR (Ser. A) No 3 (1983) para 64. 153 Orakhelashvili (n 41) 466-7.

154 Rawle Kennedy $v$ Trinidad and Tobago, UN Doc CCPR/C/67/D/845/1999 (31 December 1999) para $17 . \quad 155$ Belilos $v$ Switzerland, 132 EurCtHR (ser. A) (1988).

156 R Jennings and A Watts, Oppenheim's International Law vol 1 (9th edn, Longman 1995) 1242 , '[s]ince a reservation is a unilateral act by the party making it, evidence from that party's internal sources regarding the preparation of the reservation is admissible to show its intention in making the reservation'. $\quad{ }_{157}$ Fisheries Jurisdiction (n 111) para 49.

158 Anglo-Iranian Oil Co Primary Objection, Judgment, (1952) ICJ Rep 107, para 107.

159 Weber $v$ Switzerland [1990] ECHR 13, para 36.

160 Restrictions to the Death Penalty (Arts. 4(2) and 4(4) of the American Convention on Human Rights), Advisory Opinion OC-3/83, September 8, 1983, Inter-AmCtHR (Ser. A) No. 3 (1983) 63-64. 
reasonable way, having due regard to the intention of the State concerned at the time when it accepted the compulsory jurisdiction of the Court. ${ }^{161}$

The Guide to Practice and Commentary acknowledged the fact that the unilateral character of reservations has had an effect on how reservations ought to be interpreted. In its Commentary to Guideline 4.2.6 on the interpretation of reservations, the ILC explained:

Since reservations are unilateral acts, the Commission based itself on the guidelines for interpreting such acts contained in the Guiding Principles applicable to unilateral declarations of States capable of creating legal obligations, which it adopted in 2006. It should not be forgotten, however, that reservations are acts attached to a treaty, the legal effect of which they purport to modify or exclude. Consequently, the treaty is the context that should be taken into account for the purposes of interpreting the reservation. ${ }^{162}$

Guideline 4.2.6 of the Guide to Practice therefore provided that:

A reservation is to be interpreted in good faith, taking into account the intention of its author as reflected primarily in the text of the reservation, as well as the object and purpose of the treaty and the circumstances in which the reservation was formulated. ${ }^{163}$

Two aspects of Guideline 4.2.6 are worthy of attention. First, as noted above, where reservations are viewed as unilateral acts, the exercise of interpreting reservations seek to honour the intention of the author, placing due emphasis on the text of the reservation. ${ }^{164}$ Moreover, Guideline 4.2.6 is correct to refer to circumstances surrounding the formulation of a reservation as references to ascertaining intention - an indication that the issue of intention is a question of fact not a question of law. ${ }^{165}$ In Rawle Kennedy $v$ Trinidad, the HRC concluded that the State party's denunciation of, and immediate re-accession to, the Optional Protocol subsequent to the HRC's earlier pronouncement on the severability of a reservation was a strong indication that the State party did not intend to be bound by the treaty without the benefit of the reservation:

In these particular circumstances it is quite clear that Trinidad and Tobago was not prepared to be a party to the Optional Protocol without the particular reservation, and that its re-accession was dependent on [the] acceptability of that reservation. It

161 Fisheries Jurisdiction (n 111) para 49. For a justification on why certain rules applicable to reservations on declarations of acceptances should analogously apply to reservations to treaties, see text accompanying (nn 111-115). $\quad 162$ Guide to Practice and Commentary (n 11) 468.

163 Guideline 4.2.6, Guide to Practice.

164 Note that, unlike art 31(1) of the Vienna Convention, Guideline 4.2.6 does not mention the 'ordinary meaning' of the terms. Art 31(1) of the Vienna Convention provides that: 'A treaty shall be interpreted in good faith in accordance with the ordinary meaning to be given to the terms of the treaty in their context and in the light of its object and purpose.'

165 Brownie (n 14) 641-2, 'While the principle applied by the Court - that a unilateral declaration may have certain legal effects ... when the declaration is not directed to a specific state or states but is expressed erga omnes, as here, the detection of an intention to be legally bound, and of the structure of such intention, involves very careful appreciation of the facts.' 
follows that if we had accepted the Committee's view that the reservation is invalid we would have had to hold that Trinidad and Tobago is not a party to the Optional Protocol. ${ }^{166}$

The second aspect worthy of attention is its reference to the object and purpose of the treaty. Unlike other unilateral acts, reservations are necessarily statements that arise in the context of a treaty. Therefore, rules concerning the interpretation of reservations have to be adapted to the sui generis character of an expression to be bound by a treaty. ${ }^{167}$ Commentary on Guideline 4.2 .6 explains that ' $[\mathrm{t}] \mathrm{he}$ exogenous elements to consider in the interpretation of the reservation should include the object and purpose of the treaty, since the reservation is a nonautonomous unilateral act, which only produces an effect within the framework of the treaty'. ${ }^{168}$ Indeed, the reference to the object and purpose to the treaty is particularly relevant. For instance, when the reserving State formulates a reservation, it is presumed that the State did not intend to defeat its intention to ratify the treaty by drafting a reservation that is incompatible with the object and purpose of the treaty. This reasoning was reflected in the Restrictions on Death Penalty advisory opinion:

In interpreting reservations, account must be taken of the object and purpose of the relevant treaty which, in the case of the Convention, involves the 'protection of the basic rights of individual human beings, irrespective of their nationality, both against the State of their nationality and all other contracting States'. (reference omitted) The purpose of the Convention imposes real limits on the effect that reservations attached to it can have. If reservations to the Convention, to be permissible, must be compatible with the object and purpose of the treaty, it follows that these reservations will have to be interpreted in a manner that is most consistent with that object and purpose. ${ }^{169}$ (Emphasis added.)

However, this approach is not unproblematic, especially in the context of human rights treaties. One of the rationales behind the strong emphasis placed on the intention of the reserving State is the principle that unilateral declarations and acts are generally to be interpreted in a manner consistent with the intention of the reserving State. ${ }^{170}$ Nevertheless, human rights monitoring bodies often take a different approach, arguing that inasmuch as the object and purpose of human rights treaties is to secure for individuals the

\footnotetext{
166 Rawle Kennedy v Trinidad and Tobago, UN Doc CCPR/C/57/D/845/1999 (31 December 1999) para 17. For an analysis of HRC's decision, see G McGrory, 'Reservations of Virtue? Lessons from Trinidad and Tobago's Reservation to the First Optional Protocol' (2001) 23(3) Hum RtsQ 769.

167 Fisheries Jurisdiction (n 111) para 46; 'The Court observes that the provisions of that Convention may only apply analogously to the extent compatible with the sui generis character of the unilateral acceptance of the Court's jurisdiction.'

168 Guide to Practice and Commentary (n 11) 470.

169 Restrictions to the Death Penalty (Arts 4(2) and 4(4) of the American Convention on Human Rights), Advisory Opinion OC-3/83, September 8, 1983, Inter-AmCtHR (Ser. A) No 3 (1983) para 65.

170 See text accompanying (nn 59-63).
} 
rights provided under these treaties, ambiguities arising from any restrictions on these rights should be interpreted in the interest of rights-holders. Thus, in the Effect of Reservations on the Entry into Force of the American Convention on Human Rights Advisory Opinion, the IAmCHR reasoned:

[M]odern human rights treaties in general, and the American Convention in particular are not multilateral treaties of the traditional type concluded to accomplish reciprocal exchange of rights for mutual benefit of the contracting States. Their object and purpose is the protection of the basic rights of individual human beings, irrespective of their nationality, both against the State of their nationality and all other contracting States. In concluding these human rights treaties, the States can be deemed to submit themselves to a legal order within which they, for the common good, assume various obligations, not in relation to other States, but towards all individuals within their jurisdiction. ${ }^{171}$ (Emphasis added.)

The precise effect of the above is uncertain and the question may reasonably be asked whether, when faced with two possible interpretations, preference will be afforded to the interpretation that maximizes the protection afforded to individuals rather than the one that best reflects the intention of the reserving State, ie whether ambiguities in reservations would be resolved contra proferentem. ${ }^{172}$ The Guide to Practice and Commentary acknowledges the potential inconsistency without providing an affirmative answer. ${ }^{173}$

\section{CONCLUSIONS: TOWARDS A 'HYBRID’ APPROACH TO RESERVATIONS}

To conclude, the approach taken by the ILC to construe reservations as nonautonomous unilateral acts has far-reaching implications. Once a reservation is taken as a (non-autonomous) unilateral act, certain aspects of reservations are to be governed by the laws applicable to unilateral acts. Moreover, since a unilateral act is an expression of consent, the intention of the State plays a significant role in determining the scope of consent that the reserving State has given when the reservation was made. Therefore, the intention of the

171 Effect of Reservations on the Entry into Force of IAmCHR (n 42) para 29.

$172 \mathrm{cf}$ Fisheries Jurisdiction (n 111) para 43. In arguing that a reservation on the declaration of acceptance of the ICJ's compulsory jurisdiction should be interpreted narrowly, Spain invoked the concept of contra proferentem and argued that where ambiguity arises, a reservation should be interpreted against the reserving State because a reserving State shall not be allowed to undermine the Court's compulsory jurisdiction while accepting it. One may similarly argue that a State shall not be allowed to undermine the effectiveness of a human rights treaty in providing human rights safeguards and guarantees, and thus should be interpreted narrowly. Nevertheless, the concept of contra proferentem was rejected by the ICJ in the case. There is currently no settled principle yet as to how reservations in human rights treaties ought to be interpreted. Studies on the issues seem pertinent.

${ }^{173}$ Guide to Practice and Commentary (n 11) 471, 'The question therefore arises of whether, by their nature, human rights treaties require the application of specific principles of interpretation. It goes without saying that the answer to this question far exceeds the scope of the present Guide to Practice.' 
reserving State becomes particularly relevant in interpreting the scope of the reservation as well as the consequences of impermissibility. In this respect, the Guide to Practice envisaged a 'hybrid' approach where the laws of unilateral acts and the law of treaties overlap in the context of reservations. While the former is relevant when consent is at issue, the latter continues to apply to formal procedures, including the withdrawal, suspension and termination of reservations. Most interestingly, such a construction provided plausible answers to a series of highly complex questions:

1. Since reservations are unilateral acts, the permissibility of a reservation depends entirely on its compatibility with the object and purpose of the treaty (unless it is expressly or impliedly provided otherwise). Acceptances and objections by States may be useful in assessing the compatibility of reservations, yet they are not conclusive. Imagining reservations as unilateral acts entails that the permissibility of a reservation can be objectively determined by a dispute settlement mechanism.

2. An impermissible reservation is void ab initio, ie void at the time it was formulated. Subsequent acceptances and non-objections will not render an otherwise illegal unilateral act lawful.

3. When an interpretation of reservation is involved, the emphasis is placed on the intention of the reserving State as to the scope and content of the reservation.

4. The consequence of an impermissible reservation also depends on the intention of the reserving State at the time when the reservation was made. This includes whether the reserving State intended to be bound by the treaty without the benefit of the reservation if a reservation is subsequently found impermissible. Severability is presumed on the assumption that the reserving State did not intend to frustrate its own accession to the treaty in the first place by submitting a reservation that would defeat the treaty's object and purpose.

It remains to be seen whether States and international judicial/quasi-judicial bodies will endorse ILC's novel approach to reservations. Yet, while not legally binding, the Guide to Practice is bound to be impactful and will certainly provide lawyers with guidance in their future practice. For academics, it will continue to be a valuable source for reflection. 